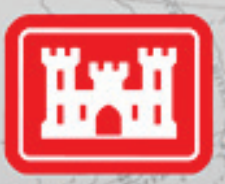

US Army Corps of Engineers ${ }_{\circledast}$

\title{
Hydraulic Dike Effects Investigation on the Mississippi River: Natchez to Baton Rouge
}

MRG\&P Report No. 37 • May 2021

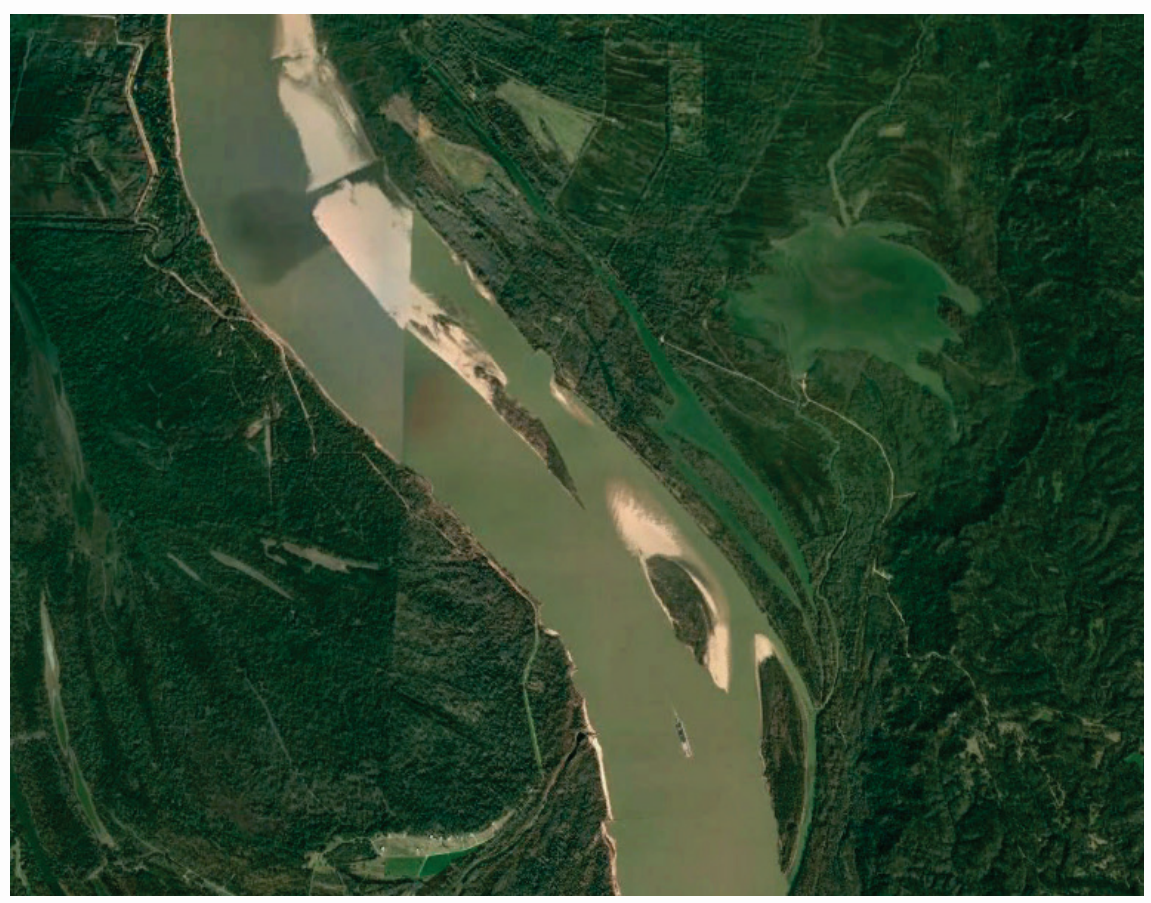

$\mathrm{MRG \& P}$

Mississippi River

Geomorphology \& Potamology Program 



\section{Hydraulic Dike Effects Investigation on the Mississippi River: Natchez to Baton Rouge}

David P. May, David S. Biedenharn, Tate O. McAlpin, and Ty V. Wamsley

Coastal and Hydraulics Laboratory

U.S. Army Engineer Research and Development Center

3909 Halls Ferry Road

Vicksburg, MS 39180-6199

Final report

Approved for public release; distribution is unlimited.

Prepared for Mississippi Valley Division, Science and Technology Office

Vicksburg, MS 39180

Under Project No. 470711 


\section{Abstract}

This report documents an investigation of the hydraulic effects of dikes on water levels in the Mississippi River between Natchez, MS, and Baton Rouge, LA, conducted for the U.S. Army Corps of Engineers, Mississippi Valley Division, Vicksburg, MS. The investigation was conducted using a previously calibrated Natchez-to-Baton Rouge Adaptive Hydraulics numerical model. The objectives were to alter roughness and height variables associated with the dikes and overbanks encompassed in the numerical model and evaluate their effects on water surface elevations. This academic exercise provides an indication of the relative level of impact associated with modifications to the dikes and overbanks for this portion of the Mississippi River and does not represent future plans or recommendations by the U.S. Army Corps of Engineers. Steady flow simulations were simulated for 12 May 2011 to investigate the variation in model results during the peak of the 2011 flood on the Mississippi River.

DISCLAIMER: The contents of this report are not to be used for advertising, publication, or promotional purposes. Citation of trade names does not constitute an official endorsement or approval of the use of such commercial products. All product names and trademarks cited are the property of their respective owners. The findings of this report are not to be construed as an official Department of the Army position unless so designated by other authorized documents. 


\section{Contents}

Abstract

2 Model Characteristics.................................................................................................................

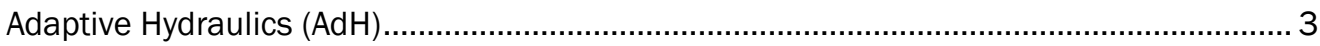

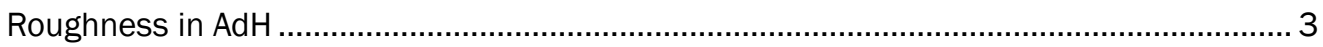

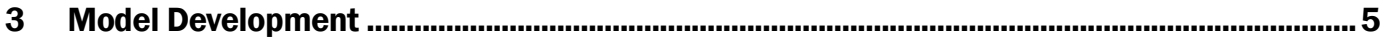

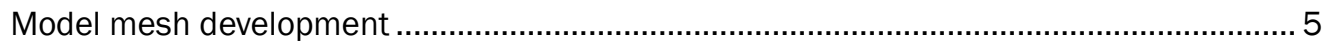

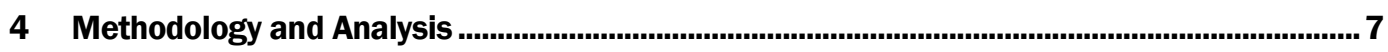

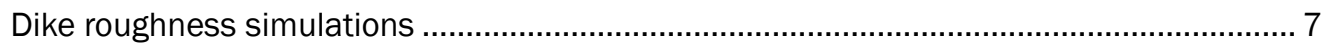

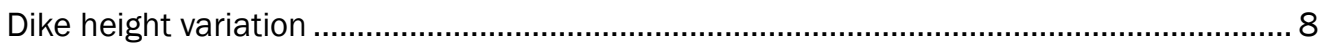

Overbank roughness variations ................................................................................... 10

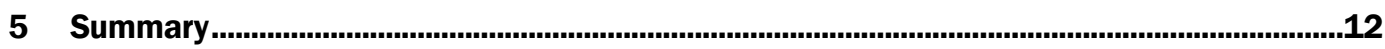

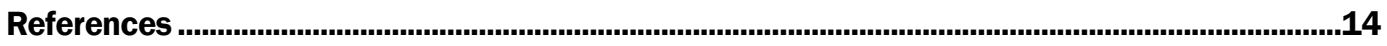

Unit Conversion Factors ...........................................................................................................15

Report Documentation Page 


\section{Figures}

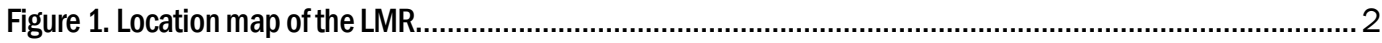

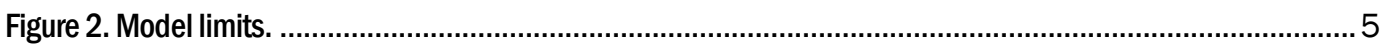

Figure 3. Numerical model mesh of dikes, channel and overbank. ............................................................. 6

Figure 4. Flood water surface elevation comparison for dike roughness variations. ............................................. 8

Figure 5. Water surface elevation comparison for dike height increases and removal.........................................

Figure 6. Dike roughness variations water surface elevation comparison for flood conditions................................ 9

Figure 7. Water surface elevation comparison for overbank roughness variation. ..............................................11

Figure 8. Water surface elevation comparison for overbank roughness variation in inches...................................11

Figure 9. Water surface elevation comparison for dike height increases and overbank roughness variation in inches. 


\section{Preface}

The research documented in this report was conducted for the Mississippi Valley Division, Science and Technology Office, as part of the Mississippi River Geomorphology and Potamology (MRG\&P) Program, under Project No. 470711. The MRG\&P Program is part of the Mississippi River and Tributaries Project and is managed by the U.S. Army Corps of Engineers, Mississippi Valley Division (MVD). At the time of publication of this report, the MRG\&P Program Director was Dr. James W. Lewis. The MVD Commander was MG Diana M. Holland, and the MVD Director of Programs was Mr. Edward E. Belk.

The work was performed by the River and Estuarine Engineering Branch of the Flood and Storm Protection Division, U.S. Army Engineer Research and Development Center, Coastal and Hydraulics Laboratory (ERDC-CHL). At the time of publication of this report, Mr. David P. May was Chief of the River and Estuarine Engineering Branch, and Dr. Cary A. Talbot was Chief of the Flood and Storm Protection Division. The Deputy Director of ERDCCHL was Mr. Keith Flowers, and Dr. Ty V. Wamsley was the Director.

The Commander of ERDC was COL Teresa A. Schlosser, and the Director was Dr. David W. Pittman. 


\section{Introduction}

\section{Background}

The Natchez-to-Baton Rouge Adaptive Hydraulics (AdH) model was originally created to investigate hydraulics and sediment transport as detailed in Leech et al. (2018). To capture complex processes, the Natchez-to-Baton Rouge model possessed a very high-resolution mesh with detailed bathymetry data. The AdH mesh included all 28 dikes present in the $150+$ miles of channel represented in the model domain. All dikes were input into the mesh from as-built drawings to ensure correct length, height, and elevation. Modern bathymetric surveys from 2004 were used in the mesh creation process. Consequently, all channel elevations in the mesh adequately reflect the system for the time period simulated in this investigation.

Dikes, as implemented on the Lower Mississippi River (LMR) (Figure 1), serve to maintain a minimum navigation channel; for the shallow draft section of the river upstream of Baton Rouge, this is $300 \mathrm{ft}^{*}$ wide and $9 \mathrm{ft}$ deep. Systems of dikes on the Lower Mississippi River achieve these specifications by narrowing the main channel and thus concentrating the flow. Through these mechanisms, the main channel undergoes deepening, increased flow velocity, and subsequently, more sediment transport. The resulting increase in channel depth, channel velocities, and sediment transport directly decreases the need for dredging. The Mississippi River Geomorphology and Potamology (MRG\&P) Program is presently engaged in empirical, analytical, and numerical modeling efforts to provide a comprehensive assessment of the morphological effects of dike systems in the LMR. This study reflects just one component of these overall investigations. This study does not include sediment transport or morphological impacts associated with the construction of dikes or any other system modifications discussed in this report.

\footnotetext{
* For a full list of the spelled-out forms of the units of measure used in this document, please refer to US Government Publishing Office Style Manual, 31st ed. (Washington, DC: US Government Publishing Office 2016), 248-52, https://www.govinfo.gov/content/pkg/GPO-STYLEMANUAL-2016/pdf/GPOSTYLEMANUAL-2016.pdf.
} 
Figure 1. Location map of the LMR.

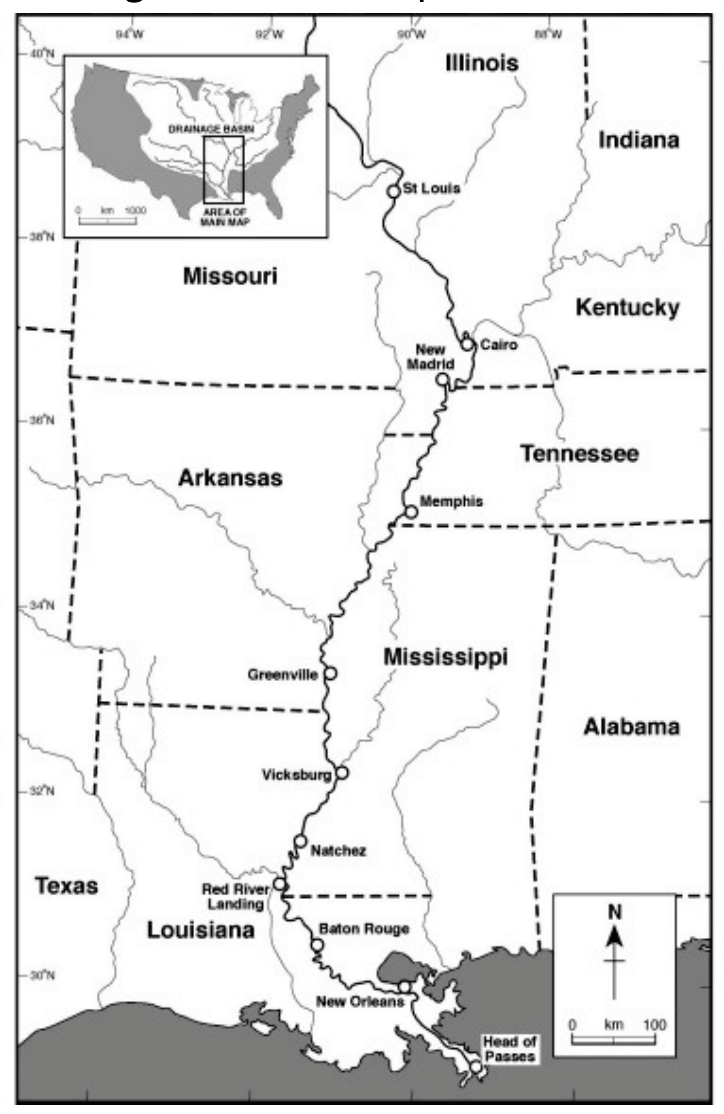

\section{Objectives}

The primary objectives of this study were to (1) examine the effects of dike fields on water surface elevations using an existing two-dimensional (2D) fixed-bed AdH model for the Natchez-to-Old River reach of the LMR and (2) compare these results to theoretical changes in the overbank roughness for this reach.

\section{Approach}

The approach for this study was as follows:

- Assemble and analyze all data pertinent to numerical model development. (e.g., bathymetry, infrastructure, roughness characteristics, boundary condition data)

- Modify the previously developed computational mesh; roughness and physical characteristics of dikes

- Vary height and roughness of all dikes within the bounds of the mesh and record resulting water surface elevation impacts

- Vary overbank roughness within the bounds of the mesh and record resulting water surface elevation impacts. 


\section{Model Characteristics}

\section{Adaptive Hydraulics (AdH)}

The AdH model is a finite element model that is capable of simulating three-dimensional (3D) Navier Stokes equations, 2D and 3D shallow water equations, and groundwater equations. It can be used in a serial or multiprocessor mode on personal computers, UNIX, Silicon Graphics, and CRAY operating systems. For this study, AdH was applied in 2D depthaveraged mode on a multiprocessor CRAY system.

The adaptive aspect of $\mathrm{AdH}$ is its ability to dynamically refine the domain mesh in areas where more resolution is needed at certain times during the simulation due to changes in the flow and/or transport conditions. AdH also has an adaptive time-stepping capability where the model can reduce the time-step during a simulation to improve the convergence values. AdH can simulate the transport of conservative constituents, such as dye clouds, as well as sediment transport that is coupled to bed and hydrodynamic changes. The ability of AdH to allow the domain to wet and dry as the tide and/or river stage changes is important for simulating the Mississippi River and associated flood plain over the wide range of flows common to the system. This tool has been developed at the U.S. Army Engineer Research and Development Center, Coastal and Hydraulics Laboratory, and has been used to model sediment transport in such varied environments as the Mississippi River (Brown et al. 2019), tidal conditions in Anchorage, AK (McAlpin et al. 2013), and vessel traffic in the Houston Ship Channel (Tate et al. 2008).

\section{Roughness in AdH}

In AdH models, the roughness value for a material type (or region) can be easily adjusted via the boundary condition file. Note that AdH does not employ the classic form of Manning's equation. The classic form of Manning's equation was originally developed empirically and is only approximately valid over a limited range of roughness-to-depth ratios. The $\log$ profile roughness utilized in $\mathrm{AdH}$, however, is theoretically based and hence is valid over the full range of roughness-to-depth ratios, as long as the flow is in the turbulent, rough range. While the variation between the two methods is nominal in-channel, it can be significant in the floodplains. For 
this reason, the assigned roughness values in AdH differ numerically from classic Manning's $n$ values commonly discussed in the literature.

More details about AdH and its computational philosophy and equations can be found in Savant et al. (2020) and ERDC (2017a,b). 


\section{Model Development}

\section{Model mesh development}

The mesh of the model (Leech et al. 2018) used in this effort extends from Natchez, MS (364 river miles above Head of Passes, or River Mile [RM] 364) on the Mississippi River to Baton Rouge, LA, at RM 228 (Figure 2). The mesh extends east and west to the elevation of highest flood for the period of record or to the levees, where applicable. Twenty-eight river training structures (dikes), thirty-two revetments, and the Hog's Point trench filled revetment were identified and resolved in the model. The Old River Control structures and the Morganza Control Structure were also included in the model. Figure 2 shows the complete model domain. The mesh elevation data were specified using 2004 lidar (overbanks) and multi-beam (channels) bathymetry data. The mesh domain includes over 330,000 acres (1,335 thousand $\left.\mathrm{km}^{2}\right)$, over 452,000 elements, and approximately 227,000 nodes. The mesh resolution (Figure 3 ) is set such that the river channel has $50 \mathrm{~m}$ spacing on average; the element size increases toward the mesh boundaries and decreases over the river training structures. The horizontal coordinate system used for this application is the State Plane Coordinate System (NAD27), Louisiana South zone (FIPS 1702), meters. The vertical coordinate system is NAVD88, meters.

Figure 2. Model limits.

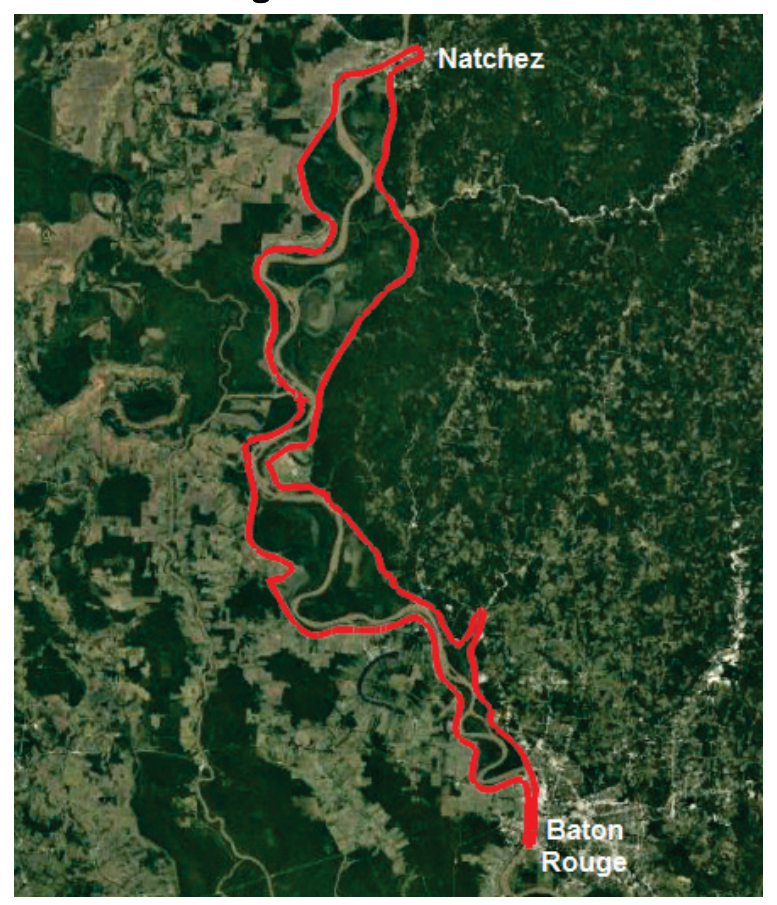


Figure 3. Numerical model mesh of dikes, channel and overbank.

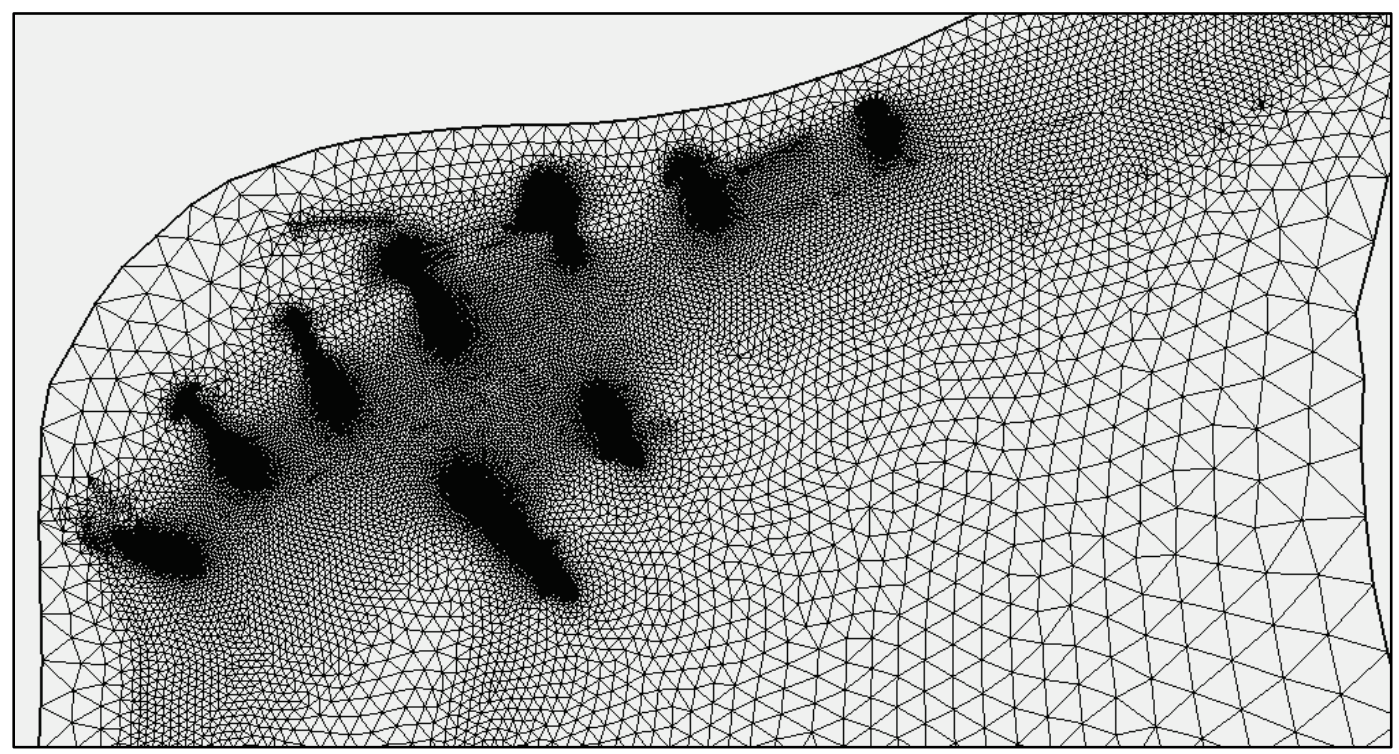




\section{Methodology and Analysis}

\section{Dike roughness simulations}

The Natchez-to-Baton Rouge AdH model was previously calibrated for a range of flows (see Leech et al. [2018] for details), but for the purpose of this effort, a steady-state flood condition was simulated. The impact of dikes at normal flows is widely accepted to be limited to the concentration of flow and improved sediment transport, both of which lead to a reduction in dredging requirements. However, there has been some debate about the hydrodynamic effects of dike systems during flood events. This model was utilized to determine the water surface elevation impacts of the dikes for this reach of the river.

All dikes in the Natchez-to-Baton Rouge model were calibrated to a Manning's roughness value of 0.035 (Leech et al. 2018). To investigate the dike roughness impact on the water levels during a flood event, the roughness for the dikes material type was varied by the following percentages: $28 \%, 57 \%, 85 \%$, and $100 \%$. These percent increases yielded Manning's $n$ values of .045, .055, .065, and .07, respectively. These variations in dike roughness were simulated with a flow of 2,000,000 cfs at the upstream boundary at Natchez, MS. Water surface elevations were recorded for every river mile of the main channel Mississippi River encompassed within the AdH model.

The results of the dike roughness simulations are shown in Figure 4. As seen in these figures, the roughness variations of the dike systems result in negligible change in the water surface elevations along the main channel during flood flows. 
Figure 4. Flood water surface elevation comparison for dike roughness variations.

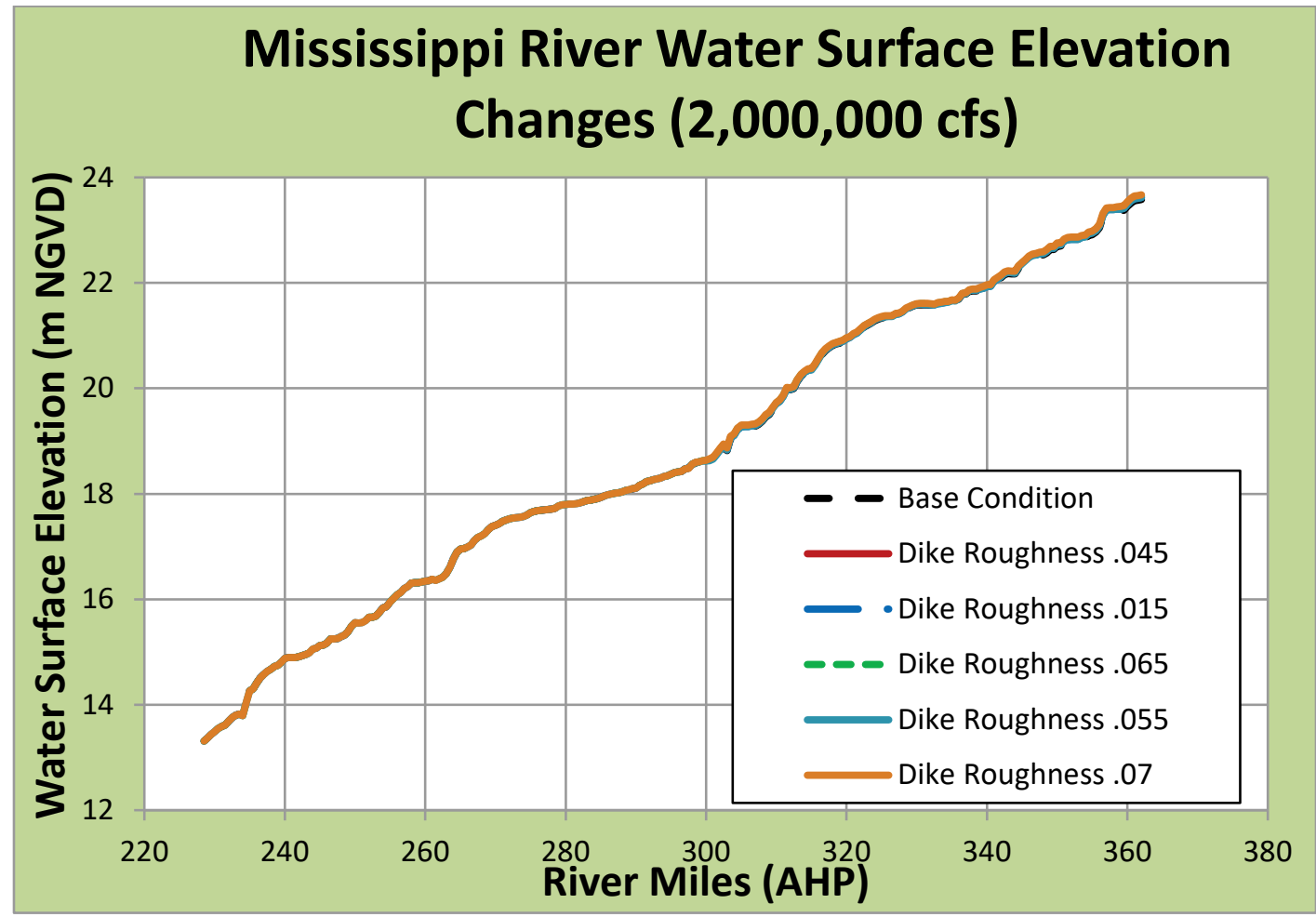

\section{Dike height variation}

To evaluate the effects of adjusting the physical obstruction of flow, the heights of the individual dikes in all dike systems encompassed in the model were altered. Height increases of approximately 5 and $10 \mathrm{ft}$ were applied to every dike in the model domain. Once again, these mesh geometry adjustments were simulated with a flood discharge of 2,000,000 cfs. As shown in Figure 5, these increases in dike heights ( 5 and $10 \mathrm{ft}$ ) resulted in negligible changes in water surface elevation.

Another simulation was performed whereby all the dikes in the mesh domain were removed. The results of the without-dikes simulation are shown in Figure 6. The complete removal of the dikes, as compared to the existing conditions, led to water surface elevation changes on the inch scale. 
Figure 5. Water surface elevation comparison for dike height increases and removal.

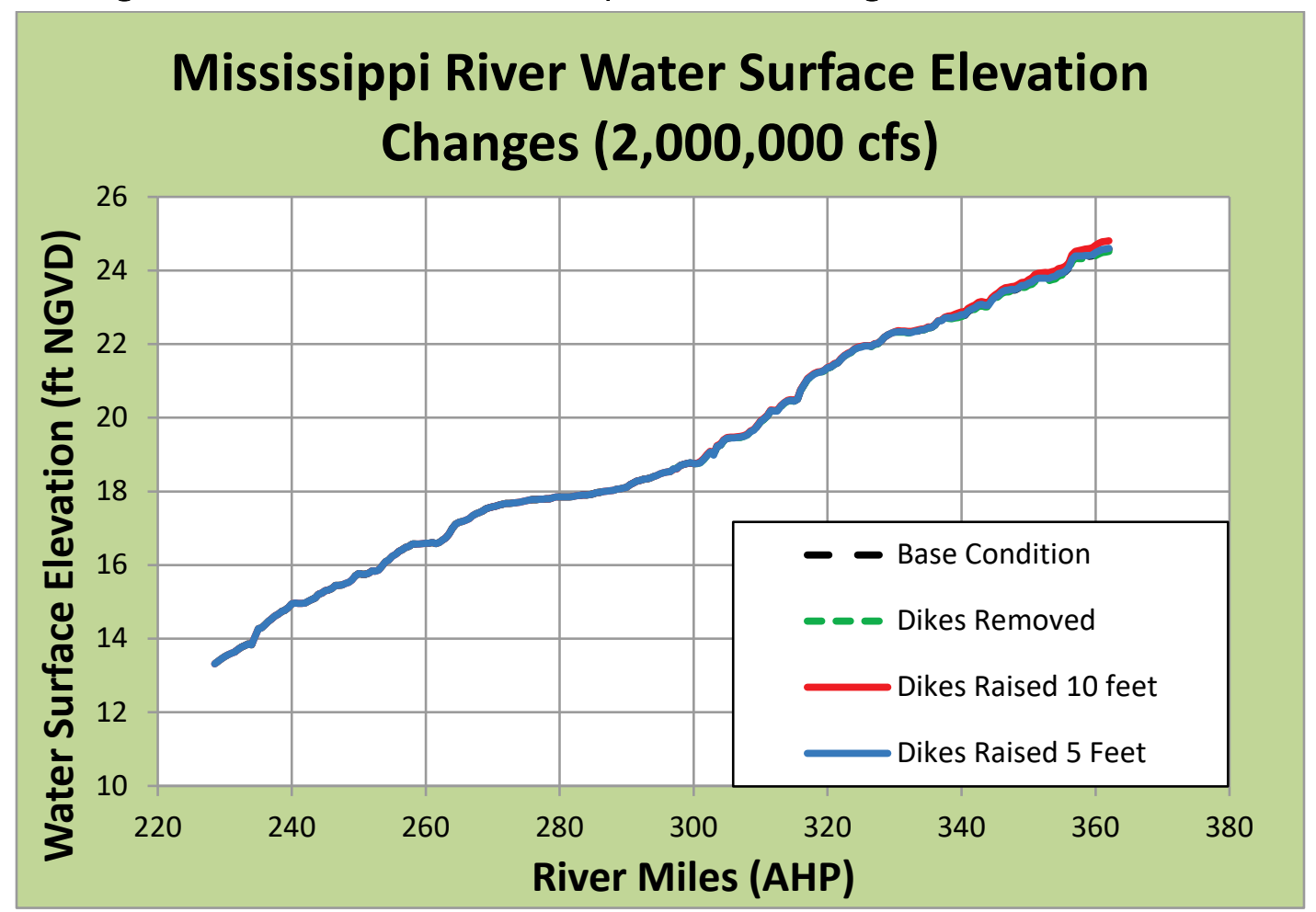

Figure 6. Dike roughness variations water surface elevation comparison for flood conditions.

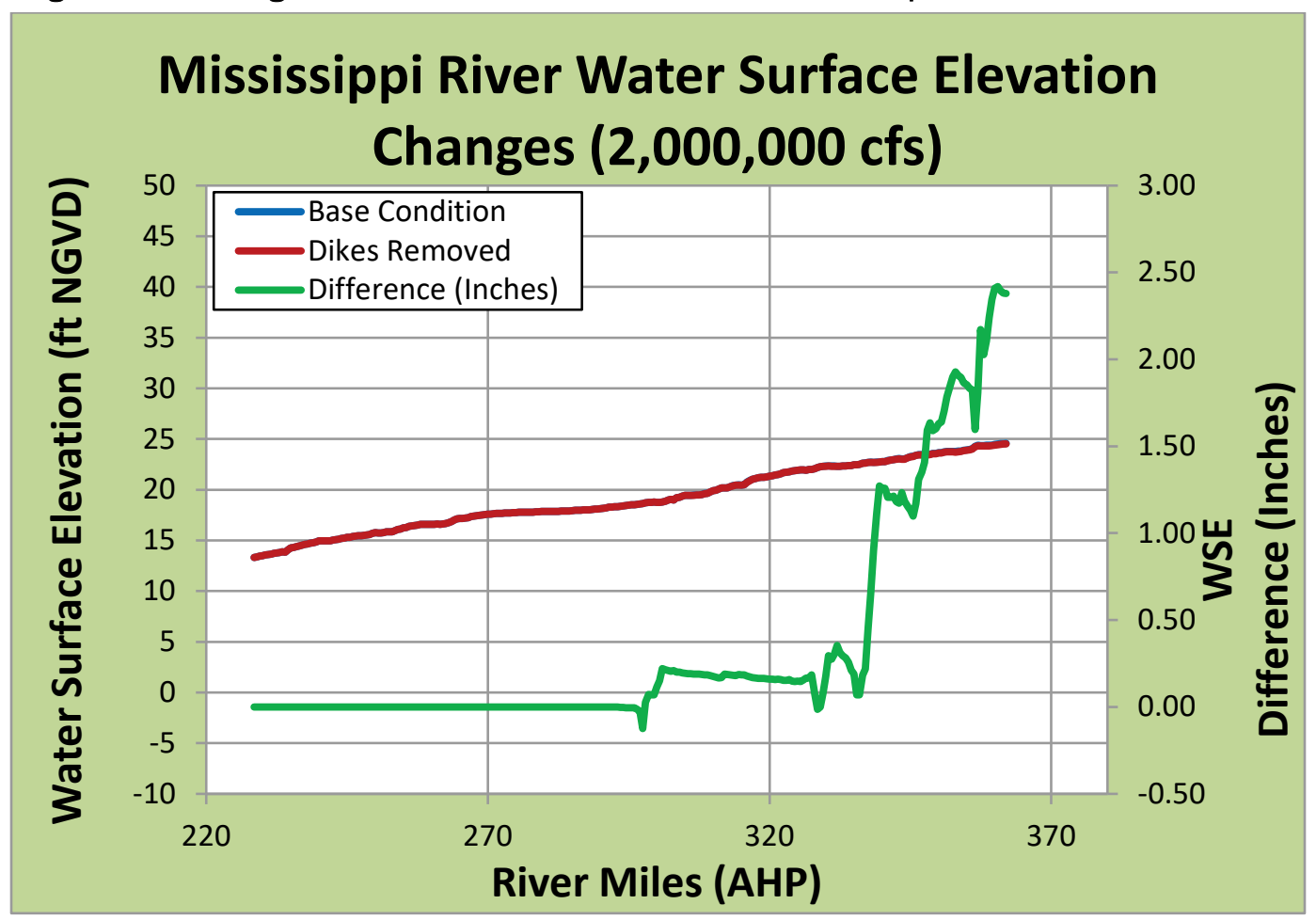


In interpreting these results, two important factors must be recognized. First, all dike modification simulations resulted in only inch-level changes in water surface elevations, which from a river engineering and modeling perspective is considered insignificant. Next, it must be recognized that this was a fixed bed model. It also must be recognized that this is simply an initial, short-term effect that could be quickly offset by sediment transport responses, such as increased local scour of the main channel, which could negate some or even all of the initial area loss. Capturing this morphologic response would require a moveable bed model, which was beyond the scope of this study.

The previous results indicate a negligible impact on flood stage water levels due to the presence of dike structures. To provide a relative comparison to the dike effects, it was decided to investigate the sensitivity of roughness changes in the overbank areas.

\section{Overbank roughness variations}

The LMR floodplain, although contained within levees, is still considerably large. A recent MRG\&P study found the average width of the batture area (area between the levees or hill line) was approximately 6.5 miles, and in many areas the width is between 10 and 15 miles (Biedenharn et al. 2018). The overbank area of the floodplain represents a substantial area of flow for the Mississippi River at flood stages. The overbank area of the Natchezto-Baton Rouge model is represented by a material type with an assigned Manning's $n$ value of 0.056. As an academic exercise, the overbank friction was increased to investigate the water level impacts and primary parameters impacting flood levels in the Mississippi River. The $n$ value of the overbank material type was increased to values of 0.0627 and 0.084 , which translates to roughness increases of $13 \%$ and $50 \%$, respectively. The results of the aforementioned simulations are provided in Figure 7 and Figure 8. The differences in Figures 7 and 8 indicate modification of the overbank friction results in variations on the order of feet in the water levels as opposed to the aforementioned dike impacts on the order of inches (Figures 5 and 6). Note that the water level variations decrease at the downstream end, exhibiting the effect of the numerical model's specified downstream boundary conditions. This phenomenon can be seen in the plots throughout this report. Also, these results do not include sediment transport or any long-term morphological change that could occur due to modification of the dike heights and roughness values or the overbank roughness values. 
Figure 7. Water surface elevation comparison for overbank roughness variation.

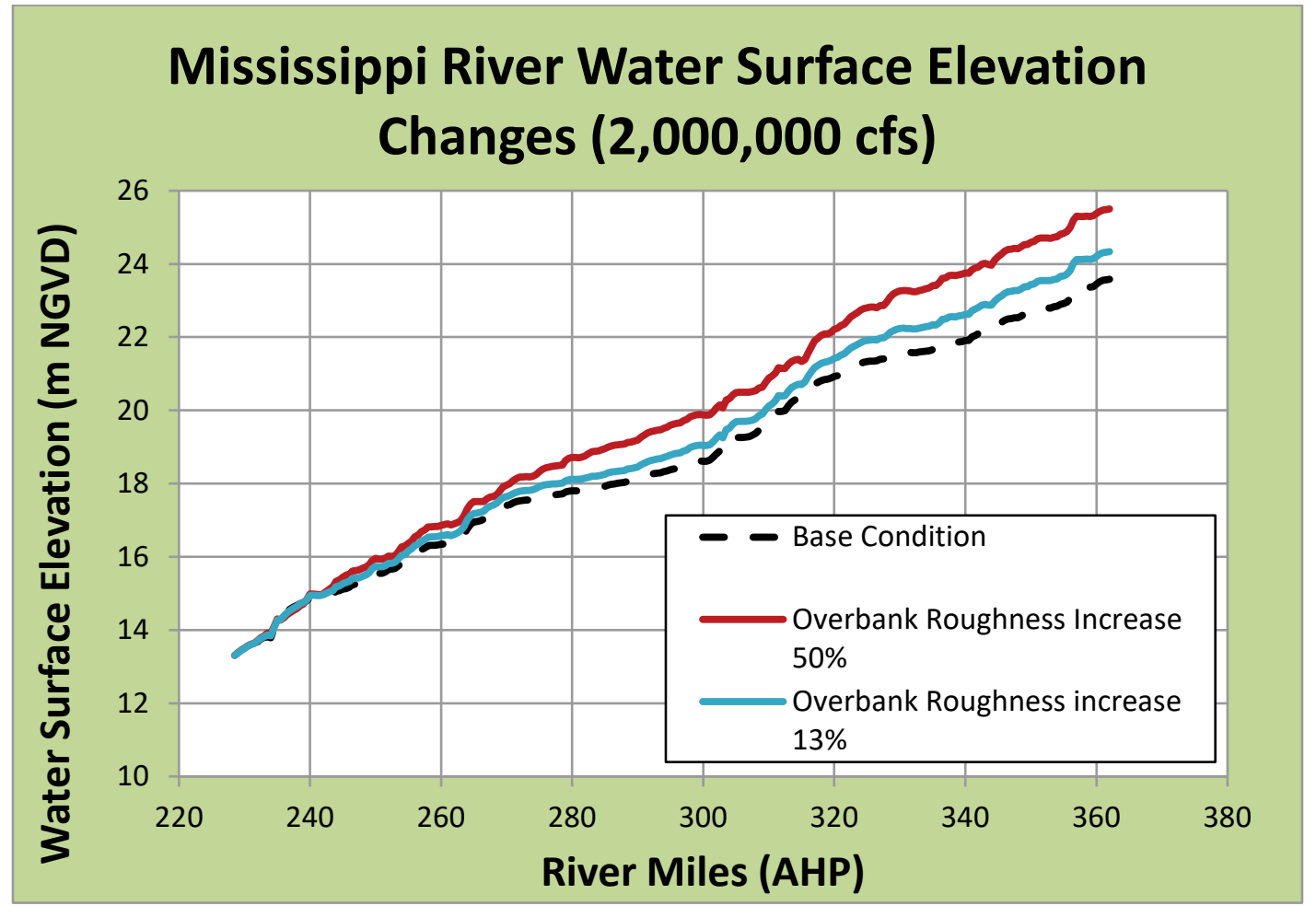

Figure 8. Water surface elevation comparison for overbank roughness variation in inches.

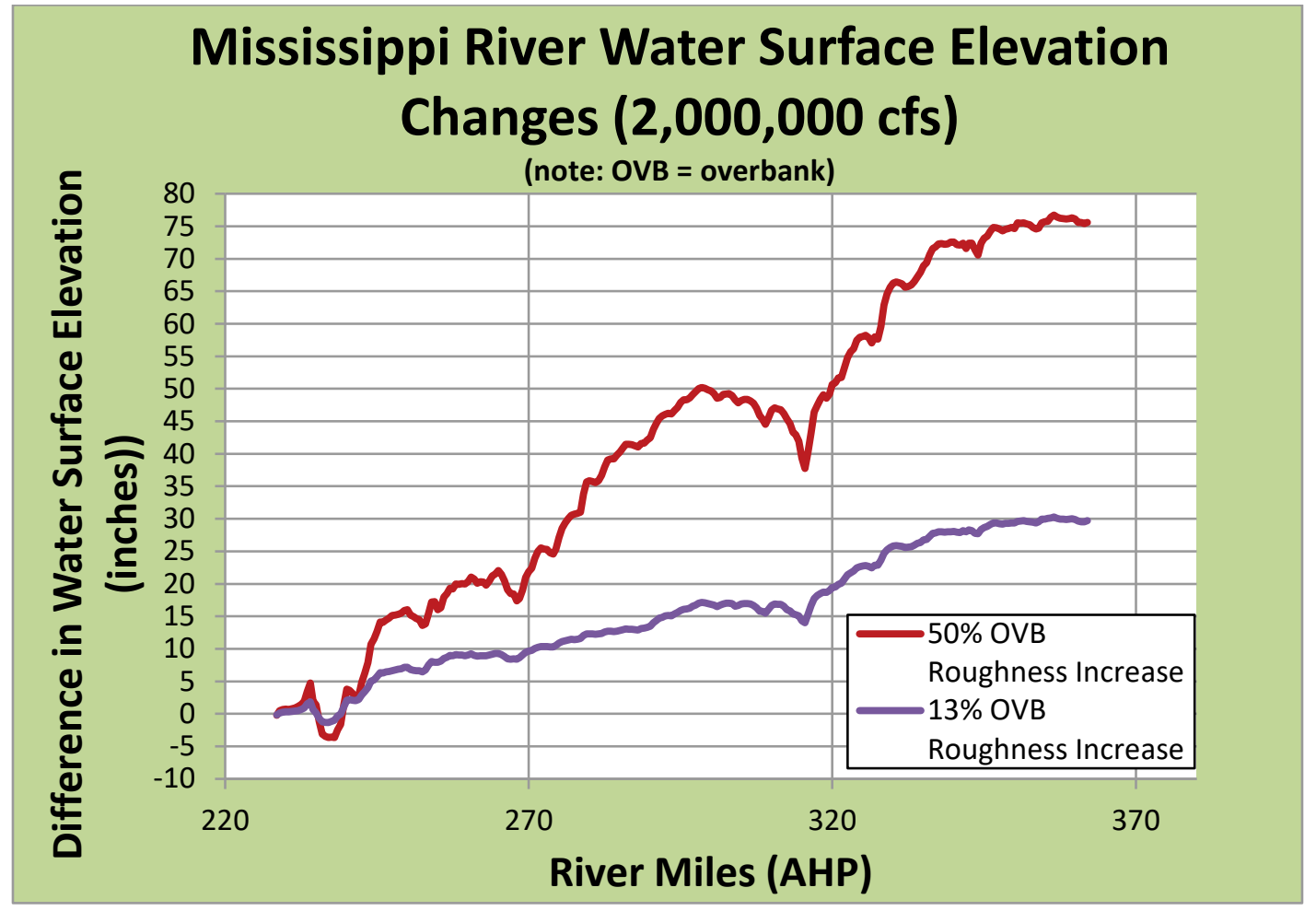




\section{Summary}

At flood flows for this section of the LMR, the height, roughness, or complete lack of river training structures impose inch-level variability on water surface elevations. Dike systems on the LMR have performed as intended, as evidenced by consistent navigability and the drastically reduced dredging amounts required by the U.S. Army Corps of Engineers upstream of Baton Rouge. The dike systems' hydraulic impact on Mississippi River stage has been investigated in the past and continues through empirical, analytical, and in this case, numerical investigations. This effort is not intended to provide a singular answer in quantifying the impact of these structures on the LMR. However, in conjunction with ongoing and historic studies, the results of this effort provide further evidence that the dike systems impose no significant impact on water surface elevations in flood or mid-bank flow conditions. Conversely, this study produced results that suggest that hypothetical adjustments to overbank roughness can have a dramatic effect on flood stages (Figure 9). While this was a limited investigation with a focus on only one area of the LMR, the results do provide considerable insight into the complex issue of in-channel and overbank effects on flood stages. Further understanding of these complex processes is critical to the effective long-term management of the LMR and continues to be a primary focus area of the MRG\&P Program. 
Figure 9. Water surface elevation comparison for dike height increases and overbank roughness variation in inches.

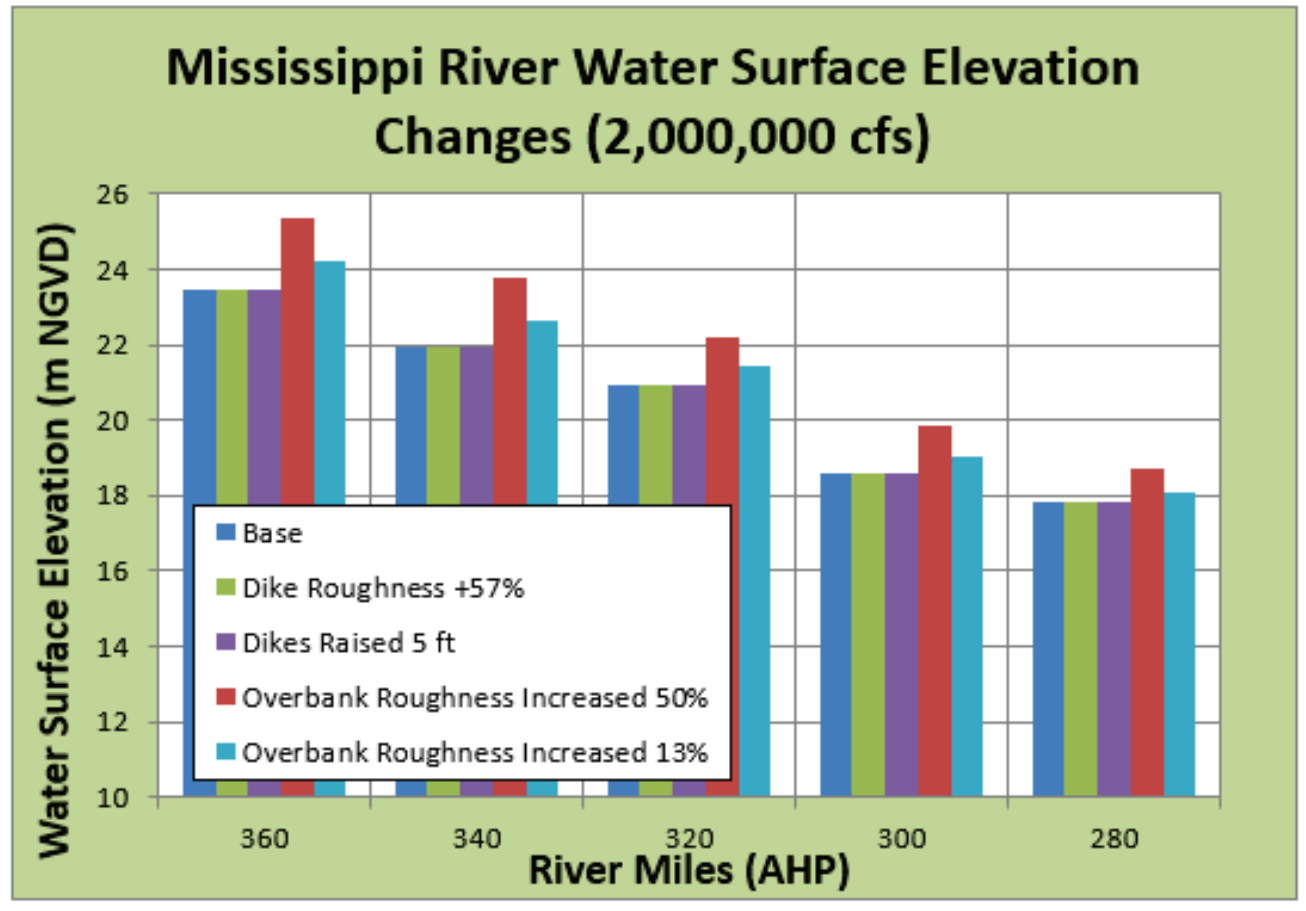




\section{References}

Biedenharn, D. S., K. J. Killgore, C. D. Little, Jr., C. E. Murphy, and B. A. Kleiss. 2018. Attributes of the Lower Mississippi River Batture. MRG\&P Technical Note No. 4. Vicksburg, MS: U.S. Army Engineer Research and Development Center.

Brown, Gary L., Jennifer N. McAlpin, Kimberly C. Pevey, Phu V. Luong, Cherie R. Price, and Barbara A. Kleiss. 2019. Mississippi River Hydrodynamic and Delta Management Study: Delta Management Modeling: AdH/SEDLIB MultiDimensional Model Validation and Scenario Analysis Report. ERDC/CHL TR19-2. Vicksburg, MS: U.S. Army Engineer Research and Development Center.

ERDC (U.S. Army Engineer Research and Development Center). 2017a. Adaptive Hydraulics 2D Shallow Water (AdH SW2D ) User Manual (Version 4.6). https://erdclibrary.erdc.dren.mil/jspui/bitstream/11681/39080/1/AdH_Manual_HydrodynamicVersion4.6.pdf

ERDC. 2017b. Adaptive Hydraulics (AdH) Version 4.6 Sediment Transport User Manual.

https://erdclibrary.erdc.dren.mil/jspui/bitstream/11681/39080/2/AdH_Manual_Sediment_TransportVersion4.6.pdf

Leech, James R., David P. May, and Tate O. McAlpin. 2018. Mississippi River: Natchez to Baton Rouge Hydraulic and Sediment Transport Model. MRG\&P Report No. 19. Vicksburg, MS: U.S. Army Engineer Research and Development Center.

McAlpin, Tate O., Gaurav Savant, Gary L. Brown, S. Jarrell Smith, and Raymond S. Chapman. 2013. "Hydrodynamics of Knik Arm: Modeling Study." Journal of Waterway, Port, Coastal and Ocean Engineering 139(3): 232-246.

Savant, G., R. C. Berger, G. L. Brown, and C. J. Trahan. 2020. Theory, Formulation, and Implementation of the Cartesian and Spherical Coordinate Two-Dimensional Depth-Averaged Module of the Adaptive Hydraulics (AdH) Finite Element Numerical Code. ERDC/CHL TR-20-8. Vicksburg, MS: U.S. Army Engineer Research and Development Center.

Tate, J. N., R. C. Berger, and C. G. Ross. 2008. Houston-Galveston Navigation Channels, Texas Project, Navigation Channel Sedimentation Study, Phase 2." ERDC/CHL TR-o8-8. Vicksburg, MS: U.S. Army Engineer Research and Development Center. 


\section{Unit Conversion Factors}

\begin{tabular}{|l|c|l|}
\hline Multiply & By & To Obtain \\
\hline Acres & $4,046.873$ & square meters \\
\hline Feet & 0.3048 & meters \\
\hline Inches & 0.0254 & meters \\
\hline
\end{tabular}




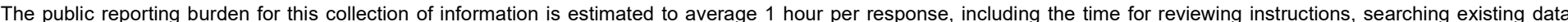

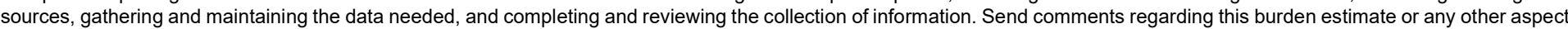

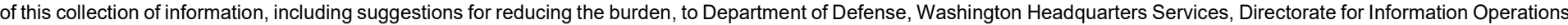

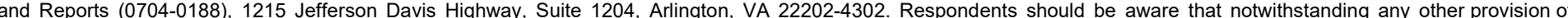
law, no person shall be subject to any penalty for failing to comply with a collection of information if it does not display a currently valid OMB control number. PLEASE DO NOT RETURN YOUR FORM TO THE ABOVE ADDRESS.

\begin{tabular}{l|l|l}
$\begin{array}{l}\text { 1. REPORT DATE } \\
\text { May } 2021\end{array}$ & $\begin{array}{l}\text { 2. REPORT TYPE } \\
\text { Final Report }\end{array}$ & 3. DATES COVERED (From - To)
\end{tabular}

\section{TITLE AND SUBTITLE}

Hydraulic Dike Effects Investigation on the Mississippi River: Natchez to Baton Rouge 5a. CONTRACT NUMBER

5b. GRANT NUMBER

5c. PROGRAM ELEMENT NUMBER

5d. PROJECT NUMBER

470711

5e. TASK NUMBER

5f. WORK UNIT NUMBER

8. PERFORMING ORGANIZATION REPORT NUMBER 1400 Walnut Street Vicksburg, MS 39180

\section{PERFORMING}

Coastal and Hydraulics Laboratory

U.S. Army Engineer Research and

Development Center

3909 Halls Ferry Road

Vicksburg, MS 39180-6199

9. SPONSORING/MONITORING AGENCY NAME(S) AND ADDRESS(ES)

Mississippi Valley Division, Science and Technology Office

Vicksburg, MS 39180
MRG\&P Report No. 37

10. SPONSOR/MONITOR'S ACRONYM(S) MVD

\section{SPONSOR/MONITOR'S} REPORT NUMBER(S)

\section{DISTRIBUTION/AVAILABILITY STATEMENT}

Approved for public release; distribution is unlimited.

\section{SUPPLEMENTARY NOTES}

\section{ABSTRACT}

This report documents an investigation of the hydraulic effects of dikes on water levels in the Mississippi River between Natchez, MS, and Baton Rouge, LA, conducted for the U.S. Army Corps of Engineers, Mississippi Valley Division, Vicksburg, MS. The investigation was conducted using a previously calibrated Natchez-to-Baton Rouge Adaptive Hydraulics numerical model. The objectives were to alter roughness and height variables associated with the dikes and overbanks encompassed in the numerical model and evaluate their effects on water surface elevations. Steady flow simulations were simulated for 12 May 2011 to investigate the variation in model results during the peak of the 2011 flood on the Mississippi River.

\section{SUBJECT TERMS}

Dikes (Engineering), Hydraulic models, Hydraulic structures, Mississippi River—Streamflow, Mississippi River-Water levels

\section{SECURITY CLASSIFICATION OF:}

\begin{tabular}{|l|l|l|}
\hline a. REPORT & b. ABSTRACT & c. THIS PAGE \\
Unclassified & Unclassified & Unclassified \\
\hline
\end{tabular}

17. LIMITATION OF ABSTRACT

SAR
18. NUMBER

OF PAGES

23 19a. NAME OF RESPONSIBLE PERSON James W. Lewis

19b. TELEPHONE NUMBER (Include area code) 601-634-5062 